\title{
Unlimited Liability and Law Firm Organization: Tax Factors and the Direction of Causation
}

\author{
Ronald J. Gilson \\ Stanford University
}

In a recent issue of this Journal, Carr and Mathewson (1988) test a model of the impact of limited and unlimited liability regimes on the nature of firms by comparing the performance of law firms operated as partnerships and sole proprietorships (and therefore subject to unlimited liability) with that of law firms operated as corporations (and therefore subject to limited liability). ${ }^{1}$ In their model, "unlimited liability by raising the cost of ownership rights discourages investment in the firm, causing legal firms to be inefficiently small" (p. 779). The peculiar history of organizational form in the legal profession seemed to provide an opportunity to test their model's prediction. Prior to the 1960 s, state law prevented law firms from incorporating, with the effect that unlimited liability was mandated. During the 1960s and early 1970s, a large number of states passed statutes that allowed law and other professional service firms to incorporate, thereby giving such firms the option to elect either an unlimited or a limited liability regime. The result was a universe that included some law firms that were subject to unlimited liability and some that were subject to limited liability.

Carr and Mathewson test their model's prediction that law firms would reach a larger, more efficient size under a limited liability regime by using 1972 and 1977 census data to compare firm size based on liability status. Consistent with their model's prediction, they report "that liability status significantly affects law firm size: a change in liability status from unlimited to limited increases the average law firm size in 1972 (as measured by annual receipts) by approximately $\$ 79,000$ (in 1972 dollars) or 48 percent. A similar result flows from the 1977 data" (p. 781).

While their use of a convenient change in the state regulation of

I am grateful to Joseph Bankman, William Klein, Myron Scholes, and an anonymous referee for comments on an earlier draft of this comment.

${ }^{1}$ The authors also test their model using data on Scottish banking between 1795 and 1882. My comments (and expertise) are limited to their discussion of law firms.

[Joumal of Polttical Economy, 1991, vol 99, no. 2]

(c) 1991 by The University of Chicago. All rights reserved. 0022-3808/91/9902-0009\$01.50 
law firm organization to test their model is quite clever, the absence of deeper inquiry into the institutional setting in which that change took place may have resulted in the authors' getting the direction of causation exactly backward. Rather than a change in liability status causing better economic performance, as Carr and Mathewson posit, it is more likely the case that, for law firms, better economic performance caused the change in liability status.

Central to understanding the pattern of law firm incorporation in the United States is that the choice is income tax, not liability, driven. Prior to the 1960s, state law did not allow corporations to render professional services. This put professionals at a substantial tax disadvantage compared with corporate employees. Most important, the Internal Revenue Code authorized corporations that adopted pension and profit-sharing plans to currently deduct contributions to such plans, while excluding the contributions from employee income and exempting from tax the income earned by the plans (Munnell 1982, pp. 30-61). Sole proprietors and partners had much more limited recourse to these benefits. ${ }^{2}$

Professionals sought to avoid this disadvantage by arguing under familiar tax principles that their firms, although not corporations, were "associations taxable as corporations" and therefore were entitled to favorable corporate tax treatment for their pension and profitsharing plans. The Internal Revenue Service (IRS) resisted these efforts until, in United States v. Kintner (216 F.2d 418 [9th Cir. 1954]), the Court of Appeals held that the IRS could not deny corporate tax status to an association of physicians when the association had the primary characteristics, although not the actual form, of a corporation. The IRS grudgingly acquiesced to the court's position by adopting regulations that allowed professional associations to be taxed as corporations, but only if state law permitted such associations certain characteristics of a corporation (Treasury regulations secs. 301.7701-1 to $301.7701-3$ [1960]). It was in response to these regulations that states adopted statutes authorizing incorporation by professional firms, thereby assuring them the availability of favorable tax treatment (Cavitch 1988, p. 81-8). Limited liability simply was not a factor. ${ }^{3}$

\footnotetext{
${ }^{2}$ While the treatment of pension plans is the most significant tax benefit from incorporation, other benefits also exist. These include the ability to provide group life insurance of up to $\$ 50,000$ per employee and medical expense reimbursement payments, in both cases with the premiums and payments deductible by the corporation and nontaxable to the employee (Cavitch 1988, pp. 81-3-81-4).

${ }^{3}$ Indeed, different states provide quite different amounts of limited liability to professional corporations. In particular, some statutes, such as those of Wisconsin and Maine, provide that a professional shareholder is liable for the acts of other shareholders to the same extent as if the shareholder were a partner (Eaton and Church 1987, pp. 9-44.2-9-46).
} 
With that background, the result that the value of the tax benefits provided by incorporation increases with the success and therefore the size of the firm flows straightforwardly from two facts. First, during the period at issue, the tax rates applicable to lawyers' income were highly progressive and for part of the period reached a top marginal rate of 70 percent. ${ }^{4}$ Second, the empirical evidence concerning law firm profitability strongly suggests that profit per partner is positively correlated with firm size.

With a focus on increased pension contributions, the most important tax advantage of incorporation, the tax value of incorporating is given by multiplying the increase in allowable pension contribution that results from incorporation by the individual partner's marginal tax rate. If partners in large firms earn more than partners in small firms, then their marginal tax rates are higher than those of partners in small firms, and the tax value of incorporation is greater for large firms. My result - that success leads to limited liability rather than, as Carr and Mathewson posit, limited liability leading to successfollows.

Suppose that a large firm earns $\$ 100,000$ per partner and that each partner's marginal tax rate is 70 percent. For the large firm, the value of the increased pension deduction resulting from incorporation is $\$ 5,250$ per partner. ${ }^{5}$ Now suppose that a small firm earns only $\$ 50,000$ per partner and that each partner's marginal rate is only 35 percent. $^{6}$ For the small firm, the value of the increased pension deduction resulting from incorporation is only $\$ 1,312$ per partner. ${ }^{7}$ The difference in the tax value of incorporation between large and small firms results from the proportional increase in tax savings due to the large firm's greater profit per partner and the more than proportional increase in tax savings due to the large-firm partners' higher marginal tax rate.

\footnotetext{
${ }^{4}$ The Tax Reform Act of 1969 reduced the top marginal rate for earned income to 60 percent for 1970 and to 50 percent for 1971 and thereafter.

${ }^{5}$ On these assumptions, the pension contribution per partner allowed an incorporated firm is roughly $\$ 20,000$ and that allowed an unincorporated firm is roughly $\$ 12,500$. The value of incorporating is 70 percent of the difference.

${ }^{6}$ These tax rates were chosen to illustrate the point. I have not tried to select rates that were in place at one time or another during the relevant period. In all events, as long as the rate structure is progressive, the outcome is the same.

${ }^{7}$ For incorporated small firms, the tax value of the pension contribution is $\$ 3,500$, assuming $\$ 50,000$ of earnings that is paid out 80 percent $(\$ 40,000)$ as salary and 20 percent $(\$ 10,000)$ as pension contribution, with a 35 percent marginal income tax rate for partners. For unincorporated small firms, the tax value of the pension contribution is $\$ 2,283$, assuming the same earnings but paid out, as in $n$. $5,87.5$ percent $(\$ 43,750)$ as salary (reflecting the lower maximum contribution allowed unincorporated entities) and 12.5 percent $(\$ 6,250)$ as pension contribution, with a 35 percent marginal income tax rate for partners. The tax value of incorporation is $\$ 1,312(\$ 3,500-\$ 2,188)$.
} 
TABLE 1

Partner Compensation as a Function of Firm Size (1982)

\begin{tabular}{lccc}
\hline $\begin{array}{c}\text { Number of } \\
\text { Attorneys } \\
\text { in Firm }\end{array}$ & $\begin{array}{c}\text { Number of } \\
\text { Firms } \\
\text { in Sample }\end{array}$ & $\begin{array}{c}\text { Average Total } \\
\text { Compensation }(\$)\end{array}$ & $\begin{array}{c}\text { Total as } \\
\text { a Percentage of } \\
\text { Average for } \\
\text { Firms with } \\
2-6 \text { Attorneys }\end{array}$ \\
\hline $2-6$ & 180 & 67,184 & 100 \\
$7-11$ & 94 & 82,174 & 122 \\
$12-19$ & 104 & 91,813 & 137 \\
$20-39$ & 90 & 104,124 & 155 \\
40 or more & 62 & 118,173 & 176 \\
\hline
\end{tabular}

SourCE.-Altman \& Well (1982), pp. 71-72.

Thus as long as profits per partner are higher in larger firms, the tax advantages of incorporation are more valuable to larger firms. Both direct evidence and inferential evidence are available on this point. Both support the proposition that partners in large firms earn more than partners in small firms.

The direct evidence shows that, for example, in 1982 the average compensation per partner in firms with 40 or more lawyers was 76 percent greater than that received by partners in firms with from two to six attorneys. The overall pattern suggests a direct relation between firm size and partner compensation, as shown in table 1. This pattern is explained by the indirect evidence. A primary determinant of profit per partner in law firms is leverage-the ratio of employee lawyers to partners (Maister 1982, pp. 15, 18; Gilson and Mnookin 1989, pp. 584-85). Of the 100 most successful corporate firms for 1987, differences in leverage explain 34.3 percent of the differences among the firms in profitability per partner (Gilson and Mnookin 1989, p. 585). Thus larger firms that are capable of supporting a number of employee lawyers for each partner will generate more profit per partner than smaller firms whose partners are not similarly leveraged ${ }^{8}$

The more plausible relationship between firm size and liability regime, then, is precisely the opposite of what Carr and Mathewson posit. Choosing to incorporate may not result in increased law firm size. Rather, the tax benefits from incorporating are more valuable to members of successful, growing firms. As a result, they are more likely to incorporate for tax reasons and, only incidentally, to elect a

${ }^{8}$ Gilson and Mnookin (1985, pp. 357-71) discuss additional explanations for the relationship between firm size and profit per partner, including the proposition that the more firm-specific capital invested in the firm, the larger the bond of the quality of the firm's work. 
limited liability regime. The lesson from this mistake is important. When the subject of empirical research is firm organization, understanding the institutional context is critical, and the tax system is likely to be an important element of that context. It simply may be a good idea to run your research design by your tax lawyer. ${ }^{9}$

That still leaves the question that Carr and Mathewson really would like to answer: Is it possible to test for the importance of liability regime as a motive for law firm incorporation despite the importance of the tax system? In fact, it is possible to test directly the relative importance of taxes and liability regime on incorporation. Different states provide incorporated law firms with quite different limits on liability: for example, some states provide lawyers in incorporated law firms no protection against liability while others provide complete protection against all but an individual lawyer's own malpractice. Because the tax benefits to incorporation are uniform across states whereas the extent of limited liability differs, the rate of incorporation should be higher in states that provide more extensive liability protection if liability regime matters. In their reply to this comment (this issue), Carr and Mathewson report that they tested this hypothesis by reexamining their data in light of a classification of states based on the extent of liability protection provided by each state at the time to which their data sets relate. The results show no significant relation between extent of liability protection and incorporation, a result consistent with tax-driven incorporation but inconsistent with liabilitydriven incorporation. ${ }^{10}$

\footnotetext{
${ }^{9}$ To be sure, the tax advantages of incorporation do not explain why a substantial number of firms nonetheless have remained partnerships, thereby choosing to pay higher taxes. The point can be deflected by noting that Carr and Mathewson's limited liability explanation suffers from the same defect. The same firms that choose higher effective tax rates also choose unlimited, not limited, liability. More directly, while this is not the occasion to work out a complete account of the costs that might offset the tax benefits of incorporation, two sorts come to mind. First, Fama and Jensen (1983) argue that professional partnerships maintain unlimited liability as a bond of the unobservable quality of their services. In some cases, the tax (and liability) benefits of incorporation may be outweighed by the cost of giving up the bond. Second, one effect of a pension plan is to impose a uniform savings rate on all partners. When a firm is composed of individuals of differing ages and wealth, unanimity may not exist among the partners concerning the appropriate savings rate, even when tax savings are taken into account. While side payments between partners might facilitate the optimal outcome, the transaction cost barriers to agreement may be substantial.

${ }^{10}$ Pursuant to the suggestion of an anonymous referee, Carr and Mathewson and I divided the labor necessary to pursue this test: I provided the state-by-state classification and they undertook the statistical analysis. Thus errors in classification by me would affect their results. I am informed by Carr and Mathewson that my classification differs from their original delineation of limited and unlimited liability states; however, I do not understand that the analysis based on their original classification shows any greater relation between liability protection and incorporation. Two other approaches to testing the importance of limited liability as a motive for law firm incorporation in
} 


\section{References}

Altman \& Weil, Inc. The 1982 Survey of Law Firm Economics. Ardmore, Pa.: Altman \& Weil, 1982.

Blackburn, Boyd A. "Professional Incorporations after Tax Reform." In Proceedings of the Forty-sixth Institute on Federal Taxation, vol. 1. New York: Bender, 1988.

Carr, Jack L., and Mathewson, G. Frank. "Unlimited Liability as a Barrier to Entry." J.P.E. 96 (August 1988): 766-84.

- "Reply to Professor Gilson." J.P.E., this issue.

Cavitch, Zolman. Business Organizations: With Tax Planning. Vol. 4A. New York: Bender, 1988.

Eaton, Berrien C., Jr., and Church, David H. Business Organizations: Professional Corporations and Associations. Vol. 17. New York: Bender, 1987.

Fama, Eugene F., and Jensen, Michael C. "Agency Problems and Residual Claims." J. Law and Econ. 26 (June 1983): 327-49.

Gilson, Ronald J., and Mnookin, Robert H. "Sharing among the Human Capitalists: An Economic Inquiry into the Corporate Law Firm and How Partners Split Profits.” Stanford Law Rev. 37 (January 1985): 313-92.

- "Coming of Age in a Corporate Law Firm: The Economics of Associate Career Patterns." Stanford Law Rev. 41, no. 3 (1989): 567-95.

Maister, David H. "Balancing the Professional Service Firm." Sloan Management Rev. 24 (Fall 1982): 15-29.

Munnell, Alicia H. The Economics of Private Pensions. Washington: Brookings Inst., 1982.

\footnotetext{
light of the tax system come to mind. The first focuses on sole proprietors: one-lawyer firms. Incorporation by these firms cannot result in limited liability because under all state professional incorporation statutes the professional actually rendering services on behalf of the corporation remains personally liable. Thus all incorporations by sole proprietors must be tax motivated. It would be interesting to see whether the rate of incorporation differed between sole proprietorships and multilawyer firms. If limited liability is an important factor in the incorporation decision, the incorporation rate for multilawyer firms should be higher. (However, tax effects may cause this outcome to be overdetermined as well because increased size will increase the tax benefits of incorporation for multilawyer firms as well as the liability benefits.) The second approach builds on changes in the tax law. Beginning with the Tax Equity and Fiscal Responsibility Act of 1982 and accelerating with the Tax Reform Act of 1986, the tax benefits from operating a professional firm as a corporation have been dramatically reduced (Blackburn 1988). Some light may be shed on the relative importance of tax and liability motives for professional incorporation by examining both the rates of incorporation since 1982 as compared with prior periods and the number of professional corporations that have chosen to disincorporate-return to an unlimited liability regime-since 1982.
} 